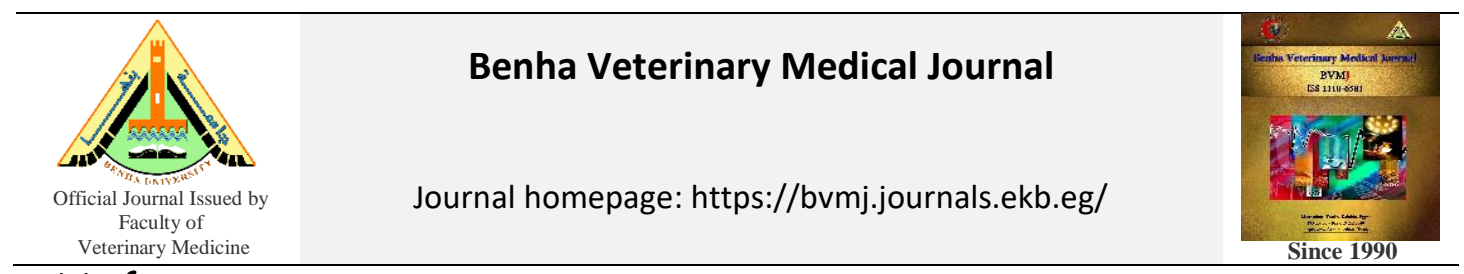

Original Paper

\title{
Biochemical role of probiotics in improving cell proliferation and regulating proinflammatory cytokines-mediated oxidative damage of ethanol-induced gastric mucosal injury in rats
}

Yakout A. El Senosi ${ }^{1}$; Mohamed k. Mahfouz ${ }^{1}$; Samy Ali Hussein ${ }^{1}$, Hagar Mahmoud Youssef ${ }^{2}$

${ }^{I}$ Biochemistry Department, Faculty of Vet. Med., Benha University, Egypt.

2 MSc Post-graduate Student

\begin{tabular}{|c|c|}
\hline ARTICLE INFO & ABSTRACT \\
\hline $\begin{array}{l}\text { Keywords } \\
\text { Ethanol } \\
\text { gastric injury } \\
\text { oxidative stress } \\
\text { Probiotics } \\
\text { proinflammatory cytokine } \\
\text { Received 23/12/2019 } \\
\text { Accepted 03/02/2020 } \\
\text { Availa6le On-Line } \\
\text { 18/07/2020 }\end{array}$ & $\begin{array}{l}\text { In the present study the gastroprotective effect and the molecular mechanisms of probiotics in } \\
\text { a rat model of ethanol-induced gastric injury were evaluated. Thirty-five male rats were divided } \\
\text { into five equal groups. Group } 1 \text { : (Control normal group) rats received no drugs. Group } 2 \text { : (Early } \\
\text { ulcer non-protected group) rats received absolute ethanol ( } 0.5 \mathrm{ml} / 100 \mathrm{~g} \text { rat) orally on an empty } \\
\text { stomach and sacrificed one hour later. Group } 3 \text { : (Probiotics protected group) rats received } \\
\text { probiotic ( } 135 \mathrm{mg} / \mathrm{kg} \text { body weight/day) orally for } 21 \text { days before ethanol administration then } \\
\text { sacrificed one hour after ethanol administration. Group } 4 \text { : (Late ulcer non-treated group) rats } \\
\text { received absolute ethanol ( } 0.5 \mathrm{ml} / 100 \mathrm{~g} \text { rat) orally on empty stomach and sacrificed after } 21 \\
\text { days. Group5: (Late ulcer + Probiotics treated group) rats first administered with absolute } \\
\text { ethanol ( } 0.5 \mathrm{ml} / 100 \mathrm{~g} \text { rat) on empty stomach at the first day of experiment then after one hour, } \\
\text { probiotic was administered ( } 135 \mathrm{mg} / \mathrm{kg} \text { body weight/day) for } 21 \text { days then sacrificed. The } \\
\text { results showed a significant increase in L-Malondialdehyde (L-MDA) and decrease in reduced } \\
\text { glutathione (GSH) concentration and Catalase (CAT) activity in stomach of gastric injury- } \\
\text { induced in rats as compared with control group. Conversely, a significant decrease in L-MDA } \\
\text { and obvious increase in GSH concentration and CAT activity were observed after probiotics } \\
\text { treatment when compared to gastric ulcerated rats. Likewise, a significant up-regulation of } \\
\text { nuclear transcription factor kappa-B (NF- } \mathrm{B} \text { ) gene expression level was observed in stomach } \\
\text { of ulcerated rats. This expression was downregulated after probiotics administration. } \\
\text { Meanwhile, a significant down-regulation of peroxisome proliferator-activated receptor } \\
\text { gamma (PPAR } \gamma \text { ) and transforming growth factor } \beta 1 \text { (TGF- } \beta 1) \text { gene were detected in ethanol- } \\
\text { induced rat gastric injury. This expression was upregulated after probiotics administration. } \\
\text { Conclusively, probiotics improving gastric cell proliferation and protect gastric mucosa against } \\
\text { injury-induced in rats via anti-inflammatory and anti-oxidative mechanisms. }\end{array}$ \\
\hline
\end{tabular}

\section{INTRODUCTION}

Gastric mucosal injury occurs when injurious and destructive factors overcome an intact mucosal defense or when the mucosal defense is impaired (Laine et al., 2008). The destructive factors such as stomach Hydrochloric Acid $(\mathrm{HCl})$, ethanol, free oxygen radicals, Helicobacter pylori and Non-Steroidal Anti-inflammatory Drugs (NSAIDs) that accelerate the gastric mucosal injury leading to gastric ulceration (Al-Wajeeh et al., 2017). The acute phase of gastric ulceration involves composite action of inflammatory cytokines like tumor necrosis factor-alpha (TNF- $\alpha$ ), interleukins (IL-6, IL-10 and IL-1 $\beta$ ), over expression of p65 subunit of nuclear factor-kappa B (NF$\kappa \mathrm{B})$, also the inflammation is further aggravated by the recruitment of inflammatory cells like neutrophils and mononuclear cells (Amirshahrokhi and Khalili, 2015). The severity and maintenance of gastric damage also depends on the generation of free radicals that are highly reactive intermediates which bring about macromolecular changes (Da Silva et al., 2013).
Ethanol is considered as an agent that induces extreme gastric ulcers as it stimulates severe instabilities in the gastric mucosa (Hiruma et al., 2009). Alcohol consumption has been commonly linked to gastric mucosal injury including gastritis, gastric ulcer and even gastric carcinoma (Franke et al., 2005). The mechanisms underlying ethanolinduced gastric ulcer have not been fully defined. Yet, mounting evidence has indicated that proinflammatory cytokines, oxidative stress and apoptosis play essential roles in its pathogenesis (Al Batran et al., 2013). Ethanol induces its gastrointestinal toxicity through several mechanisms such as stimulation of acid secretions (Laloo et al., 2013), proinflammatory cytokines, oxidative stress (Mei et al., 2012), invasion of activated neutrophils and apoptosis as well as exhaustion of mucosal cytoprotective moieties, including Nitric Oxide (NO) and prostaglandin E2 (PGE2) (Antonisamy et al., 2014). Activation of neutrophils is associated with an upregulated inflammatory response with increased gastric expression of (NF- $\kappa \mathrm{B})$ which controls the generation of proinflammatory cytokines including tumor necrosis factor- $\alpha(\mathrm{TNF}-\alpha)$. These events enlarge the

\footnotetext{
*Corresponding author: Hagar Mahmoud Youssef ; E-mail: hagar_m_youssef@yahoo.com
} 
inflammatory cascade via triggering the release of other proinflammatory mediators and enhancing further recruitment of macrophages and neutrophils, thereby exacerbating the gastric insult (Sangiovanni et al., 2013). Meanwhile, oxidative stress has been implicated in the development of ethanol-induced gastric injury where an arsenal of reactive oxygen species (ROS) generated by activated leukocytes triggers mucosal damage via lipid peroxidation and via depletion of the antioxidant defenses such as reduced glutathione (GSH), glutathione peroxidase (GPx) and the total antioxidant capacity (TAC) (Liu et al., 2012). In the clinical setting, the current approach for the management of gastric ulcers focuses on the use of proton pump inhibitors and $\mathrm{H} 2$ receptor antagonists, administration of these drugs has been associated with several adverse effects such as nausea, constipation, gynecomastia and impotence that limit their use (Halabi et al., 2014).

Numerous studies have indicated that probiotics can be used for the treatment of gastric ulcers. The idea of using probiotics arose from the study conducted by (Elliott et al., 1998). Probiotics are live microorganisms which when administered in adequate amounts are highly benefit to health (Sanders, 2003). Probiotics was found to be beneficial in liberating tropic factors, enzymes and proteins during their intestinal transit so contribute to improve the host immune defense digestion and absorption of nutrients (Buts and De, 2006). So, the ability of probiotics to modulate gut microbiota is having therapeutic potential (Nitin et al., 2016). The possible mechanisms of protection of the gastric mucosal barrier induced by probiotics are (1) Increased levels of basal mucosal prostaglandins, (2) Increased cell proliferation/apoptosis ratio, (3) Stimulation of local immune responses, (4) Release of antioxidant substances, (5) Stimulation of the expression of gastric mucins, (6) Improvement in gastrointestinal permeability, and (7) Decreases in bacterial overgrowth (Gotteland et al., 2006). Many probiotic effects are mediated through immune regulation, through balance control of proinflammatory and anti-inflammatory cytokines. From this point, probiotics can be used as innovative tools to alleviate intestinal inflammation (Isolauri et al., 2001).

Accordingly, the present study was designed to evaluate the gastroprotective effect of probiotics in a rat model of ethanol-induced gastric mucosal injury. Parameters related to gastric oxidative stress, inflammation and healing were determined in order to elucidate some of the mechanisms behind probiotics gastroprotective impact.

\section{MATERIAL AND METHODS}

\subsection{Experimental animals:}

Thirty-five white male albino rats, 6-8 weeks old and average body weight $150-170 \mathrm{~g}$ were used in the experimental investigation of this study. Rats were obtained from Laboratory Animals Research Center, Faculty of Veterinary Medicine, Benha University. Animals were housed in separate metal cages, fresh and clean drinking water. Rats were kept at constant environmental and nutritional conditions throughout the period of experiment. The animals were left 2 weeks for acclimatization before the beginning of the experiment.

2.2. Chemicals and drugs:

The drugs and chemicals used in the present study were: a. Probiotics: This product was kindly supplied from NEWDYNOVET FREE TRADE, El-montazah- Alexandria and manufactured by Multipharm. Co. USA. Probiotic is a powder added to normal saline at a dose of $\left(0.0128 \times 10^{9}\right)$ CFU per gram of rat body weight (Gupta et al., 2013) which is equivalent to $135 \mathrm{mg} / \mathrm{kg}$ b. wt. orally dissolved in normal saline (Sanchez et al., 2015).

b. Absolute ethyl Alcohol was manufactured by SigmaAldrich Pharmaceutical Chemicals Co.3050 Spruce Street and St Louis; Germany.

Induction of Gastric injury:

Rats were fasted for 18 hours and allowed free access of water prior to the administration of ethanol for gastric ulcer induction. The gastric ulcers were induced in all rats except the control group by orally administrated with absolute ethanol at a dose level of $(0.5 \mathrm{ml} / 100 \mathrm{~g} \mathrm{rat})$ (Mei et al., 2012).

\subsection{Animal grouping:}

Rats were randomly divided into five main equal groups, 7 rats each, placed in individual cages and classified as follow: Group 1: (Control Normal group): Rats received no drugs, served as control non-treated for all experimental groups.

Group 2: (Early ulcer non-protected group): Rats received absolute ethanol $(0.5 \mathrm{ml} / 100 \mathrm{~g}$ rat $)$ orally on empty stomach and sacrificed one hour later after ethanol administration.

Group 3: (Probiotics protected group): Rats received probiotic $(135 \mathrm{mg} / \mathrm{kg}$ body weight/day) orally for 21 days before ethanol administration. One hour after administration of ethanol the animals were sacrificed.

Group 4: (Late ulcer non-treated group): Rats received absolute ethanol $(0.5 \mathrm{ml} / 100 \mathrm{~g}$ rat $)$ on empty stomach and were left free and sacrificed 21 days later after ethanol administration

Group 5: (Late ulcer + Probiotics treated group): Rats first administered with absolute ethanol $(0.5 \mathrm{ml} / 100 \mathrm{~g}$ rat $)$ on empty stomach at the first day of experiment then after one hour, probiotic was administered $(135 \mathrm{mg} / \mathrm{kg}$ body weight/ day) for 21 days then sacrificed.

\subsection{Sampling:}

Gastric tissue specimen were collected from all animal groups (control and experimental groups) once at the end of 21 days.

\subsubsection{Gastric tissue for biochemical analysis:}

After 21 days of treatment with probiotics the rats were sacrificed by cervical decapitation. The stomach was quickly removed, and opened along the greater curvature using a scrapper, cleaned by rinsing with cold saline and stored at $20{ }^{\circ} \mathrm{C}$ for subsequent biochemical analysis.

Briefly, gastric tissues were cut, weighed and minced into small pieces, homogenized with a glass homogenizer in 9 volume of ice-cold $0.05 \mathrm{mM}$ potassium phosphate buffer (pH7.4) to make $10 \%$ homogenates. The homogenates were centrifuged at $6000 \mathrm{rpm}$ for 15 minutes at $4^{\circ} \mathrm{C}$ then the resultant supernatant were used for the determination of $\mathrm{L}$ Malondialdehyde (L-MDA) concentration and Catalase (CAT) enzyme activity.

Also, $0.2 \mathrm{~g}$ of stomach tissues were minced into small pieces homogenized with a glass homogenizer in $0.4 \mathrm{ml}$ of $25 \%$ metaphosphoric acid (MPA) (ref. No.: 253-433-4, SigmaAldrich, Germany), then $1.4 \mathrm{ml}$ of distilled water was added, mixed and incubated for $1 \mathrm{hr}$ and centrifuged for $10 \mathrm{~min}$ at 
$3000 \mathrm{rpm}$ then the clean supernatant was removed and used for determination of Reduced glutathione (GSH) concentration.

\subsubsection{Gastric tissue for molecular analysis:}

Rats gastric tissue were immediately excised after scarification and frozen in liquid nitrogen and then stored at $-80^{\circ} \mathrm{C}$ until used for Nuclear factor kappa B (NF-kB), peroxisome proliferator-activated receptors gamma (PPAR $\gamma)$ and Transforming growth factor $\beta 1$ (TGF- $\beta$ ) gene expression analysis by qPCR.

\subsubsection{Gastric tissue for histopathological examination:}

Gastric tissue specimens were taken from different parts of the stomach for histopathological examination. The specimens were preserved in $10 \%$ buffered neutral formalin. The fixed tissue were rinsed in tap water, dehydrated through graded series of alcohols, cleared in xylene and embedded in paraffin wax. $5 \mu \mathrm{m}$ thick sections were cut and stained with hematoxylin and eosin (H\&E) (Bancroft and Stevens, 1996) and then the tissues were examined by light microscopy.

\subsection{Analysis:}

\subsubsection{Biochemical analysis:}

Gastric tissue (L-MDA), CAT and GSH were determined according to the methods described by Ohkawa et al. (1997), Aebi (1984) and Beutler et al. (1963), respectively.

\subsubsection{Molecular analysis}

Total RNA was isolated from stomach tissue of rats using RNeasy Mini Kit (Thermo Qiagen, \#74104) according to the manufacturer's protocol. Following determination of RNA concentration and purity by Quawell nanodrop Q5000 (USA), $5 \mathrm{mg}$ of total RNA from each sample was reverse transcribed using Quantiscript reverse transcriptase. The produced cDNA was used as a template to determine the relative expression of (NF- $\mathrm{KB}),(\mathrm{PPAR} \gamma)$ and (TGF- $\beta)$ genes using Step One Plus real time PCR system (Applied Biosystem, USA) and gene specific primers. The reference gene, $\beta$ actin, was used to calculate fold change in target genes expression. The thermal cycling conditions, melting curves temperatures, and calculation of relative expression was done. For the treated groups, assessment of $2^{-\Delta \Delta C t}$ determined the fold change in gene expression relative to the control.

Forward and reverse primers sequence for real time PCR.

\begin{tabular}{|c|c|c|}
\hline Gene & $\begin{array}{l}\text { Forward primer } \\
\left(5-y_{-3}-3\right)\end{array}$ & $\begin{array}{l}\text { Reverse primer } \\
\left(\begin{array}{l}\left(5-y^{\prime} 3\right) \\
\end{array}\right.\end{array}$ \\
\hline NF-kB & CCTAGCTTTCTCTGAACTGCAAA & GGGTCAGAGGCCAATAGAGA \\
\hline PPAR $\gamma$ & GCCCTTTGGTGACTTTATGGAG & GCAGCAGGTTGTCTTGGATGT \\
\hline TGF- $\beta 1$ & AAGAAGTCACCCGCGTGCTA & TGTGTGATGTCTTTGGTTTTGTCA \\
\hline$\beta$-actin & ACCCACACTGTGCCCATCTA & CGTCACACTTCATGATG \\
\hline
\end{tabular}

\subsection{Statistical Analysis}

All the data were expressed as means \pm S.E. The statistical significance was evaluated by One-Way analysis of variance (ANOVA) using SPSS, 18.0 software, 2011 and the individual comparisons were obtained by Duncan's multiple range test (DMRT). Values were considered statistically significant when $\mathrm{p}<0.05$.

\section{RESULTS}

Effect of probiotics administration on gastric tissue L-MDA, CAT and GSH of ethanol-induced gastric injury in male rats is presented in table (1). Gastric L-MDA concentration was significantly increased in ethanol-induced rat gastric injury in both early gastric ulcer and late ulcer in comparison with normal control group. Probiotics administration to ethanolinduced gastric injury in rats showed a significant decrease in L-MDA concentration in treated and protected groups when compared to injured- non-treated groups. While, gastric CAT activity and GSH concentration were significantly decreased in ethanol-induced rat gastric injury when compared with the normal control group. Probiotics administration to ethanol- induced gastric injury in rats significantly elevated gastric antioxidant CAT activity and GSH concentration as compared to injured- non-treated groups.

The obtained results of $\mathrm{qPCR}$ in table (2) revealed a significant upregulated expression of NF- $\kappa \mathrm{B}$ gene in ethanol-induced gastric injury in rats at early and late ulcer when compared to the normal control group. This expression was significantly downregulated following administration of probiotics in treated and protected groups when compared with injured-non-treated groups. Meanwhile, a significant downregulated expression of PPAR $\gamma$ and TGF- $\beta 1$ gene were observed in ethanol-induced rat gastric mucosal injury at early and late gastric ulcer as compared to the normal control group. This expression was significantly upregulated following administration of probiotics in treated and protected groups vs injured non- treated groups.

Histopathological examination of stomach mucosa of control normal rats showed normal appearance of surface epithelium, mucous neck cells, parietal cells and chief cells of mucosa in gastric tissue of (Fig. 1a). Multifocally, there was necrosis and desquamation of the surface epithelium characterized by hyper-eosinophilic, shrunken cytoplasm with pyknotic nuclei in gastric tissue of early ulcer nonprotected group (Fig. 1b). Meanwhile, there were small erosions in the mucosa characterized by necrosis and loss of surface epithelium in gastric tissue of Probiotics protected group (Fig. 1c). Also, there were variable sizes areas of erosions primarily affecting the surface and deep mucosa in gastric tissue of Late ulcer non-treated group (Fig. 1d). The examined stomach of (Late ulcer + Probiotics treated group) revealed normal histological appearance of mucosal cells with rare small erosions in the surface epithelium and the erosive areas were characterized by necrosis and loss of the surface epithelium (Fig. 1e).

\section{DISCUSSION}

Ethanol rapidly penetrates the gastric mucosa, causing membrane injury, exfoliation of cells, erosion, and ulcer formation (Franke et al., 2005). Alcohol causes severe oxidative stress in gastric tissue, which is showed as an enhancement in lipid peroxidation that occurs via an increase in the L-MDA level and a decrease in the gastric GSH concentration (Cadirci et al., 2007). The obtained results showed significant increase in L-MDA concentration with marked decrease in CAT activity and GSH concentration in gastric tissue of ethanol-induced gastric injury in rats. Similarly, Al-Wajeeh et al. (2017) showed significant decreases in the endogenous antioxidant enzymatic activity and increased lipid peroxidation in stomach tissue of ethanol-induced gastric injury in Sprague- 
Dawley rats. In addition to, ethanol administration initiated gastric oxidative stress and increased the levels of lipid peroxides in a process driven by neutrophil activation. It also decreased and depleted the gastric GSH, glutathione peroxidase (GPx) and total antioxidant capacity (TAC), antioxidant defenses, which scavenge free radicals and prevent their detrimental effects (Park et al., 2008). Recently, Selmi et al. (2017) showed that ethanol intoxication induced an increase of the final products of lipid peroxidation, increase of hydrogen peroxide content as well as depletion antioxidant enzyme activities such as GPx, CAT and SOD.

In the current study a significant depletion of gastric tissue L-MDA and marked increase in GSH concentration and CAT activity were observed after administration of probiotics in gastric ulcer- induced rats. Similarly, Ejtahed et al. (2012) showed that there was a significant decrease in L-MDA levels in probiotic treated group after the consumption of probiotic yoghurt. Additionally, the concentration of L-MDA occurs in diabetic rats is significantly decreased after treatment with L. acidophilus probiotics (Harisa et al., 2009). Studies found that there is a protective effect of a probiotic mixture of 13 different bacteria and $\alpha$-tocopherol on ethanol-induced gastric mucosal injury. The protective effect results from its ability to reduce ethanol-induced gastric mucosal lipid peroxidation and decrease the malondialdehyde concentration, so they may be beneficial for gastric damage induced with ethanol (Senol et al., 2011). Probiotic supplementation may lead to increasing TAC and lowering MDA, which improve antioxidant status (Zamani et al., 2019). Also, Wang et al. (2009) reported that, GSH-Px activity was increased in vivo after diet supplementation with Lactobacillus fermentum and Lactobacillus plantarum. Many Lactobacillus strains which have anti-oxidative effect were found not only causing reduction in L-MDA level but also ameliorating production of antioxidant (Ejtahed et al., 2012). Probiotics can increase CAT and SOD activities, so that it has a Potential role in the management of gastric ulcer (Khoder et al., 2016).

A significant upregulation of NF- $\kappa \mathrm{B}$ gene expression level was observed in stomach of ethanol-induced gastric injury in rats as compared to control normal group. Ethanol can cause gastric epithelial injury by inducing apoptosis through the TNF- $\alpha$ pathway and through the formation of reactive oxygen species (ROS), which causes cellular damage through oxidative stress (Liu, 2014). At the same time, the expression of TNF- $\alpha$ is under the control of NF- $\kappa \mathrm{B}$ signal pathway. NF- $\kappa \mathrm{B}$ signaling pathway is involved in controlling the gene expression of multiple factors and plays an important role in immune response, inflammation, stress response, cell apoptosis, cancer, and ontogenetic development (Chen et al., 2001).

Moreover, Li et al. (2014) reported that, ethanol markedly initiated the over expression of nuclear factor- $\mathrm{kB}$ in gastric mucosa of mice exposed to ethanol. Likewise, Arab et al., (2015) showed that ethanol administration stimulate gastric inflammation by increased of NF- $\mathrm{KB}$ p 65 expression. The mRNA expression levels NF- $\kappa$ B was significantly increased in the gastric mucosa after ethanol administration (Song et al., 2016). NF- $\mathrm{KB}$ consists of $\mathrm{p} 65$ and p50 subunits while NFkB-p65 subunit has been commonly regarded as a marker for NF- $\kappa B$ activation (Verma and Kumar 2016). NF- $\kappa B$ is activated when its inhibitor, I $\mathrm{K} B$, is phosphorylated by oxidative stress and inflammatory cytokines. Consequently $\mathrm{NF}-\kappa \mathrm{B}$ is released which then translocate toward the nucleus to initiate transcription of target dependent inflammatory genes (Lawrence, 2009). This suggestion was confirmed by Katary and Salahuddin (2017), who reported that, ethanol consumption up regulated protein expression of NF- $\mathrm{KB}$ p 65 .

Table 1 Effect of probiotics administration on gastric tissue L-MDA, GSH concentration and CAT activity of ethanol-induced gastric mucosal injury in male $\underline{\text { rats }}$

\begin{tabular}{lccc} 
rats. & & & CAT (U/g tissue) \\
\hline Animal groups & L-MDA (nmol/g. tissue) & $0.933 \pm 0.04^{\mathrm{a}}$ & GSH (mg/g tissue) \\
\hline Group I: Normal control & $1.51 \pm 0.14^{\mathrm{e}}$ & $0.392 \pm 0.02^{\mathrm{d}}$ & $4.48 \pm 0.32^{\mathrm{a}}$ \\
Group П : Early ulcer non-protected & $10.20 \pm 0.52^{\mathrm{b}}$ & $0.655 \pm 0.03^{\mathrm{b}}$ & $1.19 \pm 0.12^{\mathrm{d}}$ \\
Group III: Probiotics protected & $3.64 \pm 0.34^{\mathrm{d}}$ & $0.370 \pm 0.03^{\mathrm{d}}$ & $3.55 \pm 0.26^{\mathrm{b}}$ \\
Group IV: Late ulcer non-treated & $12.29 \pm 0.73^{\mathrm{a}}$ & $0.530 \pm 0.03^{\mathrm{c}}$ & $0.81 \pm 0.05^{\mathrm{d}}$ \\
Group V : Late ulcer + Probiotics treated & $5.82 \pm 0.28^{\mathrm{c}}$ & $2.61 \pm 0.15^{\mathrm{c}}$ &
\end{tabular}

Data are presented as (Mean \pm S.E). Mean values with different superscript letters in the same column are significantly different at $(\mathrm{P} \leq 0.05)$.

Table 2 Effect of probiotics administration on the relative expression of NF- $\mathrm{BB}$, PPAR $\gamma$ and TGF- $\beta 1$ gene in stomach of ethanol-induced gastric mucosal injury in male rats.

\begin{tabular}{|c|c|c|c|c|c|c|}
\hline \multirow[t]{2}{*}{ Animal groups } & \multicolumn{2}{|c|}{$\begin{array}{l}\text { Nuclear factor kappa B } \\
\text { (NF-kB) }\end{array}$} & \multicolumn{2}{|c|}{$\begin{array}{l}\text { peroxisome proliferator-activated receptors gamma } \\
\qquad(\mathrm{PPAR} \gamma)\end{array}$} & \multicolumn{2}{|c|}{$\begin{array}{l}\text { Transforming growth factor } \beta 1 \\
\text { (TGF- } \beta 1 \text { ) }\end{array}$} \\
\hline & Fold change mean & SEM & Fold change mean & SEM & Fold change mean & SEM \\
\hline Group I: Normal control & $1.00^{\mathrm{c}}$ & 0.07 & $1.00^{\mathrm{a}}$ & 0.07 & $1.00^{\mathrm{a}}$ & 0.06 \\
\hline Group П : Early ulcer non-protected & $3.78^{\mathrm{b}}$ & 0.22 & $0.04^{\mathrm{c}}$ & 0.005 & $0.31^{\mathrm{c}}$ & 0.02 \\
\hline Group III: Probiotics protected & $1.60^{\mathrm{d}}$ & 0.09 & $0.26^{\mathrm{b}}$ & 0.03 & $0.66^{\mathrm{b}}$ & 0.04 \\
\hline Group IV: Late ulcer non-treated & $4.86^{\mathrm{a}}$ & 0.26 & $0.02^{\mathrm{c}}$ & 0.005 & $0.23^{\mathrm{c}}$ & 0.02 \\
\hline Group V : Late ulcer + Probiotics treated & $2.60^{\mathrm{c}}$ & 0.16 & $0.24^{\mathrm{b}}$ & 0.02 & $0.53^{\mathrm{b}}$ & 0.03 \\
\hline
\end{tabular}

Means within the same column carrying different superscript letters are significantly different at $(\mathrm{P}<0.05)$.

In addition, Altura et al. (2002) stated that IкB phosphorylation (and degradation) was stimulated by ethanol. In the current study the obtained results revealed a significant down-regulation of gene expression level of NF$\kappa \mathrm{B}$ following administration of probiotics in gastric injury treated groups. Probiotic bacteria can modulate systemic inflammation, cell proliferation and also apoptosis, and such properties may be useful for future immuno-modulatory and cancer prevention (Sheil et al., 2004). Pena et al. (2005) reported that $L$. reuteri mediated its anti-inflammatory effects via inhibition of NF- $\kappa \mathrm{B}$ signaling in human intestinal epithelial cells. Also, Iyer et al., (2008) stated that, because of the central role of NF- $\mathrm{KB}$ and mitogen-activated protein kinase (MAPK) signaling in inflammation, cell proliferation 
and apoptosis, it was estimated that $L$. reuteri mediated antiproliferative and pro-apoptotic effects by modulating NF- $\kappa \mathrm{B}$ and MAPK signaling pathways.

A significant down regulation in expression level of PPAR $\gamma$ and TGF- $\beta 1$ gene were observed in ethanol-induced gastric injury in rats as compared to the normal control group.
Activation of PPAR $\gamma$ has been connected with induction of cell proliferation, apoptosis, regulation of cell differentiation, and resolution of inflammation by the inhibition of NF- $\kappa \mathrm{B}$, transactivation of nitric oxide synthase2 (NOS2) and cyclooxygenase-2 (COX2) target genes.
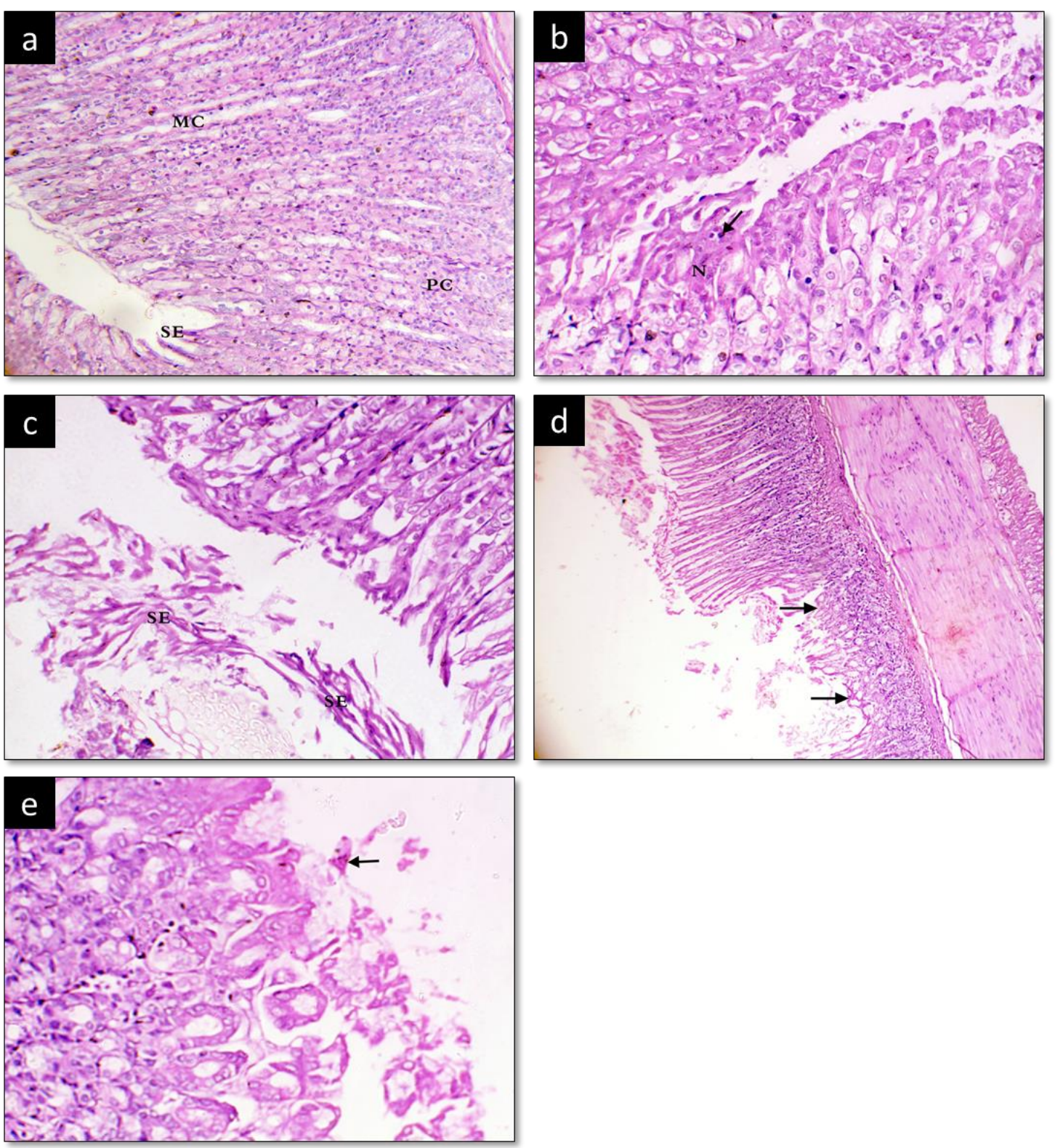

Fig. 1 Histopathological changes of rats' stomach in control and treated rats. (a) Stomach of control rats (Group 1), showing normal histological appearance of surface epithelium (SE), mucous neck cells (MC) and parietal cells (PC) ( $\times 200$ ). (b) Stomach of early ulcer non-protected rats (group 2), showing necrosis (N) of the surface epithelium characterized by hyper-eosinophilic, shrunken cytoplasm with pyknotic nuclei (arrow) ( $\times 400)$. (c) Stomach of Probiotics protected rats (Group3), showing erosion in the mucosa characterized by necrosis and loss of surface epithelium (SE) (×400). (d) Stomach of late ulcer non-treated rats (Group 4), showing marked erosions (arrow) affecting the deep mucosa $(\times 100)$. (e) Stomach of probiotic treated rats (Group 5), showing necrosis and loss of the surface epithelium (arrow) ( $\times 400)$.

The obtained results are nearly similar to the data reported by Mahmoud Awny et al. (2015), who showed a significant decrease in the gastric mRNA expression of the antiinflammatory PPAR- $\gamma$ level, with a significance up regulation in the pro-inflammatory factor $(\mathrm{NF}-\mathrm{\kappa B})$ with $\mathrm{I} / \mathrm{R}$ injury in animals. In addition, Lahiri et al. (2009), who investigated the effect of PPAR- $\gamma$ activation on proinflammatory gene expression involved in gastric ulceration and reported that, induction of ulcer caused a significant down regulation in the expression levels of PPAR- $\gamma$ in ulcer induced rats. Previous studies have showed that I/R injurious effects were mediated partially through suppressing the PPAR- $\gamma$ mRNA (Matsuyama et al., 2005), which is a transcription factor, acts as a regulator of anti-inflammation, antioxidant, and phagocyte-mediated cleanup processes. $\operatorname{PPAR} \gamma$ was found to interact negatively with other 
transcription factors as NF- $\mathrm{kB}$, which ensures its antiinflammatory/immunomodulatory effect (Zhao et al., 2015). TGF- $\beta 1$ is well known to be a multifunctional cytokine which regulates many biological processes like cell proliferation, cell differentiation, adhesion, inter cell signaling, as well as production and the degradation of extracellular matrix proteins, so that playing an essential role during wound healing and tissue repair. These results confirm that TGF- $\beta 1$ expression is part of the normal healing response of gastric tissue (Polonikov et al., 2007). TGF- $\beta$ has also been reported to modulate the (COX-2) expression. Takahashi et al. (1998) in vivo and in vitro studies was reported that COX-2 protein is localized to the base of gastric ulcers in rats and that COX-2 mRNA expression is regulated positively by IL- $1 \beta$ and TNF- $\alpha$ and negatively by TGF- $\beta 1$. From this point, TGF- $\beta 1$ plays an important role in the process of gastric ulcer healing by it interacts with prostaglandins and COX-2.

In this current study, the obtained qPCR results showed a significantly up-regulated expression of PPAR $\gamma$ and TGF- $\beta 1$ gene expression following administration of probiotics in gastric injury treated groups. Similarly, Wu et al. (2009) showed that PPAR- $\gamma$ over-expression protects mitochondrial membrane potential and prevents apoptosis by up-regulating the expression of the anti-apoptotic Bcl-2 family proteins. Likewise, Konturek et al., (2009) reported that Probiotic bacteria Escherichia coli Nissle or heal acute murine colitis via affecting gastric mucosal expression of IL- $1 \mathrm{~b}, \operatorname{PPAR} \gamma$, HSP70 and COX-2 by up regulation. Probiotic bacteria modulate gut microbial diversity and suppress colitis via targeting myeloid cell PPAR $\gamma$ (Bassaganya et al., 2012). Additionally, Zhang et al. (2013) reported that, Lactobacillus casei significantly increased numbers of Lactobacillus and Bifidobacterium and decreased Clostridium in the intestine, with up-regulation of PPAR- $\gamma$ gene expression. Besides, Kefir, koumiss, yogurt and the commercial probiotic preparation increased PPAR $\alpha$ and PPAR- $\beta / \delta$ gene expressions (Sari et al., 2013). Furthermore, Fujii et al. (2006) reported that, the administration of B. breve can up-regulate TGF- $\beta 1$ signaling and may possibly be beneficial in attenuating inflammatory and allergic reactions. TGF- $\beta$ acts through the induction and maintenance of regulatory $\mathrm{T}$ cells expressing the forkhead box P3 (FOXP3) protein or latency associated peptide (LAP). Regulatory T cells (Tregs) include different types of cells, such as CD4+CD25+ $\mathrm{T}$ lymphocytes and $\operatorname{Tr} 1$ lymphocytes. Tregs and $\operatorname{Tr} 1$ lymphocytes play an essential role in the control of local inflammation in animal models (Pronio et al., 2008).

\section{CONCULOIONS}

These findings suggest that oral treatment with probiotics showed a significant gastroprotective effects in ethanolinduced rat gastric injury as confirmed by antioxidant and anti-inflammatory activities. Also, the gastroprotective effect of probiotics might be mediated by adjustment of inflammatory mediators and increasing antioxidants defense mechanism. Moreover, probiotics administration may have the potential as an alternative treatment for gastric ulcer because of its cytoprotective and anti-inflammatory role in improving gastric mucosal healing and cell proliferation.

\section{ACKNOWLEDGMENT}

I wish to thank Prof. Dr. Shawky A. A. Moustafa, Head of Pathology Department, Faculty of Veterinary Medicine, Benha University for his great assistance in performing the Histopathological examination of gastric samples.

\section{REFERENCES}

1. Aebi, H. 1984. Catalase in vitro Methods Enzymol 105, 121 $-126$.

2. Al Batran, R.; Al-Bayaty, F.; Jamil Al-Obaidi, M.M.; Abdualkader, A.M.; Hadi, H.A.; Ali, H.M. and Abdulla, M.A. 2013. In vivo antioxidant and antiulcer activity of Parkia speciosa ethanolic leaf extract against ethanol-induced gastric ulcer in rats. PLoS One 8(5):e64751.

3. Altura, B.; Gebrewold, A.; Zhang, A. and Altura, B. 2002. Ethanol induces rapid lipid peroxidation and activation of nuclear factor-kappa B in cerebral vascular smooth muscle: relation to alcohol-induced brain injury in rats. Neuroscience Letters, 325(2), 95-98.

4. Al-Wajeeh, N.S.; Hajerezaie, M.; Suzita, M.N.; Mohammed, F.H. and Nawal, A.H. 2017. The gastro protective effects of Cibotium barometz hair on ethanol-induced gastric ulcer in Sprague-Dawley rats. BMC Vet Res 13: 27

5. Amirshahrokhi, K. and Khalili, A.R. 2015. The effect of thalidomide on ethanol-induced gastric mucosal damage in mice: Involvement of inflammatory cytokines and nitric oxide. Chem Biol Interact; 225: 63-69.

6. Antonisamy, P.; Subash-Babu, P.; Alshatwi, A.A.; Aravinthan, A.; Ignacimuthu, S.; Choi, K.C. and Kim, J.H. 2014. Gastroprotective effect of nymphayol isolat,ed from Nymphaea stellata (Willd.) flowers: contribution of antioxidant, anti-inflammatory and anti-apoptotic activities. Chem Biol Interact; 224: 157-163.

7. Arab, H.H.; Salama, S.A.; Omar, H.A.; Arafa, el-S.A. and Maghrabi I.A. 2015. Diosmin protects against ethanol-induced gastric injury in rats: novel anti-ulcer actions. PLoS One; 10(3):e0122417.

8. Bancroft, J.D. and Stevens, S.A., 1996. Theory and Practice of Histological Techniques. Churchill-Livingstone, New York. 435-470

9. Bassaganya-Riera, J., Viladomiu, M., Pedragosa, M., De Simone, C., Carbo, A., \& Shaykhutdinov, R. et al. 2012 Probiotic Bacteria Produce Conjugated Linoleic Acid Locally in the Gut That Targets Macrophage PPAR $\gamma$ to Suppress Colitis. Plos ONE, 7(2), e31238.

10. Beutler E., Duron O., Kelly MB.1963. Improved method for the determination of blood glutathione. J Lab Clin Med. 1963 May;61:882-888

11. Buts, J.P. and De, K.N. 2006: Effects of Saccharomyces boulardii on intestinal mucosa. Digestive Diseases and Science.51, 1485-1492.

12. Cadirci, E.; Suleyman, H.; Aksoy, H.; Halici, Z.; Ozgen, U.; Koc, A. and Ozturk, N. 2007. Effects of Onosma armeniacum root extract on ethanolinduced oxidative stress in stomach tissue of rats. Chem Biol Interact; 170: 40-48.

13. Chen, F.; Castranova, V. and Shi, X. 2001. New insights into the role of nuclear factor-kappaB in cell growth regulation. Am J Pathol; 159(2):387-397.

14. Da Silva, L.M.; Allemand, A.; Mendes, D.A.; Dos Santos, A.C.; André, E.; de Souza, L.M.; Cipriani, T.R.; Dartora, N.; Marques, M.C.; Baggio, C.H. and Werner, M.F. 2013. Ethanolic extract of roots from Arctium lappa L. accelerates the healing of acetic acid induced gastric ulcer in rats: Involvement of the antioxidant system. Food Chem Toxicol; 51: 179-187.

15. Ejtahed HS, Mohtadi-Nia J, Homayouni-Rad A, Niafar M, Asghari Jafarabadi M, Mofid V. 2012. Probiotic yogurt improves antioxidant status in type 2 diabetic patients. Nutrition.28: 539-543. 
16. Elliott SN, Buret A, McKnight W, Miller MJ, Wallace JL. 1998. Bacteria rapidly colonize and modulate healing of gastric ulcers in rats. Am J Physiol; 275:G425-G432.

17. Franke, A.; Teyssen, S. and Singer, M.V. 2005. Alcoholrelated diseases of the esophagus and stomach. Dig Dis; 23(34):204-13.

18. Fujii, T., Ohtsuka, Y., Lee, T., Kudo, T., Shoji, H., \& Sato, H. et al. 2006. Bifidobacterium Breve Enhances Transforming Growth Factor ??1 Signaling by Regulating Smad7 Expression in Preterm Infants. Journal Of Pediatric Gastroenterology And Nutrition, 43(1), 83-88.

19. Gotteland, M., Brunser, O. And Cruchet, S. 2006. Systematic review: are probiotics useful in controlling gastric colonization by Helicobacter pylori? Alimentary Pharmacology and Therapeutics, 23(8): 1077-1086.

20. Gupta N, Kumar A, Sharma P. 2013. Effects of the adjunctive probiotic VSL\#3 on portal haemodynamics in patients with cirrhosis and large varices: a randomized trial. Liver Int; 33: $1148-1157$

21. Halabi, M.F.; Shakir, R.M.; Bardi, D.A.; Al-Wajeeh, N.S. Ablat, A. Hassandarvish, P.; Hajrezaie, M.; Norazit, A3. and Abdulla, M.A. 2014. Gastroprotective activity of ethyl-4[(3,5-di-tert-butyl-2-hydroxybenzylidene) amino]benzoate against ethanol-induced gastric mucosal ulcer in rats. PLoS One; 9(5):e95908.

22. Harisa G.I. Taha, E.I., Khalil, A.F., Salem, M.M. 2009. Oral Administration of Lactobacillus Acidophilus Restores Nitric Oxide Level in Diabetic Rats. Aust J Basic and Appl Sci.;3:2963-2969.

23. Hiruma-Lima, C.A.; Batista, L.M.; deAlmeida, B. depietroMagri, L.; dosSantos, L.C.; Vilegas, W. and SouzaBrito, A.R. 2009. Antiulcerogenic action of ethanolic extract of the resin from Virola surinamensis Warb. (Myristicaceae). J.Ethnopharmacol; 122(2): 406-409.

24. Isolauri E, Sütas $Y$, Kankaanpää $P$, Arvilommi $H$ and Salminen S. 2001. Probiotics: Effects on immunity. Am J Clin Nutr. 73(Suppl 2): S444-S450.

25. Iyer, C., Kosters, A., Sethi, G., Kunnumakkara, A., Aggarwal, B., \& Versalovic, J. 2008. Probiotic Lactobacillus reuteri promotes TNF-induced apoptosis in human myeloid leukemia-derived cells by modulation of NF- $\mathrm{kB}$ and MAPK signalling. Cellular Microbiology, 10(7), 1442-1452.

26. Katary, M.A. and Salahuddin, A. 2017. Gastroprotective Effect of Punicalagin against Ethanol-Induced Gastric Ulcer: the Possible Underlying Mechanisms. Biomark J, 3:1

27. Khoder, G., Al-Menhali, A., Al-Yassir, F., \& Karam, S. 2016. Potential role of probiotics in the management of gastric ulcer. Experimental And Therapeutic Medicine, 12(1), 3-17.

28. Konturek, z. Sliwowski2, j. Koziel3, a. Ptak-belowska2, g. Burnat1, t. Brzozowski2, s.j. konturek2 . 2009. probiotic bacteria escherichia coli strain nissle 1917 attenuates acute gastric lesions induced by stress: journal of physiology and pharmacology, 60, suppl 6, 41-48

29. Lahiri, S.; Sen, T. and Palit, G. 2009. Involvement of glucocorticoid receptor and peroxisome proliferator activated receptor- $\gamma$ in pioglitazone mediated chronic gastric ulcer healing in rats. European Journal of Pharmacology; 609 (1-3): $118-125$

30. Laine, L., Takeuchi, K. and Tarnawski, A. 2008. Gastric mucosal defense and cytoprotection: bench to bedsideGastroenterology 135(1): A1-A46, e1-e20, 1-330.

31. Laloo, D.; Prasad, S.K.; Krishnamurthy, S. and Hemalatha, S. 2013. Gastroprotective activity of ethanolic root extract of Potentilla fulgens Wall. J Ethnopharmacol 146: 505-514

32. Lawrence, T. 2009. The nuclear factor NF-kappaB pathway in inflammation. Cold Spring Harb Perspect Biol; 1: a001651.

33. Li, W.F.; Hao, D.J.; Fan, T.; Huang, H.M.; Yao, H. and Niu, X.F. 2014. Protective effect of chelerythrine against ethanolinduced gastric ulcer in mice. Chem Biol Interact. 208:18-27.

34. Liu, C. L. 2014. The Mechanism Research of Astragalus Glysosides's Protecting Effect on Ethanol-induced GES-1
Cells Injury. Guangzhou University of Chinese Medicine, GuangDong, China.

35. Liu, Y.; Tian, X.; Gou, L.; Fu, X.; Li, S.; Lan, N. and Yin, X 2012. Protective effect of 1-citrulline against ethanol-induced gastric ulcer in rats. Environ Toxicol Pharmacol; 34(2):280 287.

36. Mahmoud Awny, M.; Attia, A.S.; Abd-Ellah, M.F. and ElAbhar, H.S. 2015. Mangiferin Mitigates Gastric Ulcer in Ischemia/ Reperfused Rats: Involvement of PPAR- $\gamma, \mathrm{NF}-\kappa \mathrm{B}$ and Nrf2/HO-1 Signaling Pathways. PLoS ONE; 10(7): e0132497.

37. Matsuyama, M.; Yoshimura, R.; Hase, T.; Uchida, J.; Tsuchida, K.; Takemoto, Y.; Kawahito, Y.; Sano, H. and Nakatani, T. 2005. Expression of peroxisome proliferatoractivated receptor-gamma in renal ischemia-reperfusion injury. Transplant Proc; 37: 1684-1685.

38. Mei, X.; Xu, D.; Xu,S.; Zheng,Y. and Xu,S. 2012. Novel role of $\mathrm{Zn}(\mathrm{II})$-curcumin in enhancing cell proliferation and adjusting proinflammatory cytokine-mediated oxidative damage of ethanol-induced acute gastric ulcers.Chem.Biol.Interact.197,31-39.

39. NitinJ, Mithun S, Rao PN, Nageshwar Reddy D. 2016. Liver Diseases: The Role of Gut Microbiota and Probiotics. J Prob Health 4: 154

40. Ohkawa, H. , Ohishi W, and Yagi K. Anal .1979. Assay for lipid peroxides in animal tissues by thiobarbituric acid reactionBiochem $95,351-8$.

41. Park, S.W.; Oh, T.Y.; Kim, Y.S.; Sim, H.; Park, S.J.; Jang, E.J.; Park, J.S.; Baik, H.W. and Hahm, K.B. 2008. Artemisia asiatica extracts protect against ethanol-induced injury in gastric mucosa of rats. J Gastroenterol Hepatol; 23(6): 976984.

42. Pena, J., Rogers, A., Ge, Z., Ng, V., Li, S., Fox, J., \& Versalovic, J. 2005. Probiotic Lactobacillus spp. Diminish Helicobacter hepaticus-Induced Inflammatory Bowel Disease in Interleukin-10-Deficient Mice. Infection And Immunity, 73(2), 912-920

43. Polonikov, A.V.; Ivanov, V.P.; Belugin, D.A.; Khoroshaya, I.V.; Kolchanova, I.O.; Solodilova, M.A.; Tutochkina, M.P. and Stepchenko, A.A. 2007. Analysis of common transforming growth factor beta-1 gene polymorphisms in gastric and duodenal ulcer disease: pilot study. J Gastroenterol Hepatol; 22(4):555-64

44. Pronio, A., Montesani, C., Butteroni, C., Vecchione, S., Mumolo, G., \& Vestri, A. et al. 2008. Probiotic administration in patients with ileal pouch-anal anastomosis for ulcerative colitis is associated with expansion of mucosal regulatory cells. Inflammatory Bowel Diseases, 14(5), 662-668.

45. Sanchez E, Nieto JC, Boullosa A, Vidal S, Sancho FJ, Rossi G Sancho-Bru P, Oms R, Mirelis B, Juárez C, Guarner C,Soriano G. 2015. VSL\#3probiotic treatment decreases bacterial translocation in rats with carbon tetrachloride-induced cirrhosis. Official Journal of the International Association for the Study of the Liver 35(3): 735 45.

46. Sanders, M.E. 2003. Probiotics: Consideration for human health. Nut. Rev; 3;(61):91-99.

47. Sangiovanni, E.; Vrhovsek, U.; Rossoni, G.; Colombo, E. Brunelli, C.; Brembati, L.; Trivulzio, S.; Gasperotti, M.; Mattivi, F.; Bosisio, E. and Dell'Agli, M. 2013. Ellagitannins from Rubus berries for the control of gastric inflammation: in vitro and in vivo studies. PLoS One; 8(8): e71762.

48. Sari, E., Bakir, B., Aydin, B., \& Sozmen, M. 2013. The effects of kefir, koumiss, yogurt and commercial probiotic formulations on PPAR $\alpha$ and PPAR $-\beta / \delta$ expressions in mouse kidney. Biotechnic \& Histochemistry, 89(4), 287-295.

49. Selmi, S.; Rtibi, K.; Grami, D.; Sebai, H. and Marzouki, L. 2017. Protective effects of orange (Citrus sinensis L.) peel aqueous extract and hesperidin on oxidative stress and peptic ulcer induced by alcohol in rat. Lipids Health Dis. 16(1):152.

50. Senol, A., Isler, M., Karahan, A., Kilic, G., Kuleasan, H., \& Kaya, S. et al. 2011. Preventive Effect of Probiotics and $\alpha$ - 
Tocopherol on Ethanol-Induced Gastric Mucosal Injury in Rats. Journal Of Medicinal Food, 14(1-2), 173-179.

51. Sheil, B., McCarthy, J., O'Mahony, L., Bennett, M.W., Ryan, P., Fitzgibbon, J.J., et al. 2004. Is the mucosal route of administration essential for probiotic function? Subcutaneous administration is associated with attenuation of murine colitis and arthritis. Gut 53: 694-700.

52. Song, J.W.; Seo, C.S.; Kim, T.I.; Moon, O.S.; Won, Y.S.; Son, H.Y.; Son, J.K. and Kwon, H.J. 2016. Protective Effects of Manassantin A against Ethanol-Induced Gastric Injury in Rats. Biol Pharm Bull;39(2):221-229.

53. Takahashi, S.; Shigeta, J.; Inoue, H.; Tanabe, T. and Okabe, S. 1998. Localization of cyclooxygenase-2 and regulation of its mRNA expression in gastric ulcers in rats. Am J Physiol.; 275: G1137-1145.

54. Verma, S. and Kumar, V.L. 2016. Attenuation of gastric mucosal damage by artesunate in rat: Modulation of oxidative stress and NFKB mediated signaling. Chem Biol Interact; 257:46-53.

55. Wang AN, Yi XW, Yu HF, Dong B, Qiao SY. 2009. Free radical scavenging activity of Lactobacillus fermentum in vitro and its antioxidative effect on growing-Wnishing pigs. J Appl Microbiol 107:1140-1148.

56. Wu, J.S.; Lin, T.N. and Wu, K.K. 2009. Rosiglitazone and PPAR-gamma overexpression protect mitochondrial membrane potential and prevent apoptosis by upregulating anti-apoptotic Bcl-2 family proteins. J Cell Physiol; 220: 5871.

57. Zamani, B., Sheikhi, A., Namazi, N., Larijani, B., \& Azadbakht, L. 2019. The Effects of Supplementation with Probiotic on Biomarkers of Oxidative Stress in Adult Subjects: a Systematic Review and Meta-analysis of Randomized Trials. Probiotics Antimicrob Proteins

$$
2020 \mathrm{Mar} ; 12(1): 102-1
$$

58. Zhang, Y., Wang, L., Zhang, J., Li, Y., He, Q., \& Li, H. et al. 2013. Probiotic Lactobacillus casei Zhang ameliorates highfructose-induced impaired glucose tolerance in hyperinsulinemia rats. European Journal Of Nutrition, 53(1), 221-232.

59. Zhao, X.; Gonzales, N. and Aronowski, J. 2015. Pleiotropic Role of PPAR $\gamma$ in Intracerebral Hemorrhage: An Intricate System Involving Nrf2, RXR, and NF-kB. CNS Neurosci Ther; 21(4): 357-366. 